\title{
The Effect of Human Capital, Labor, and Capital on Economic Growth in Barlingmascakeb
}

\author{
By: \\ Risqia Mutiara Sani ${ }^{1)}$, Herman Sambodo ${ }^{2)}$, Bambang ${ }^{3)}$ \\ ${ }^{1,2,3)}$ Faculty of Economics and Business, Universitas Jenderal Soedirman \\ ${ }^{1)}$ Email: mutiarasani@gmail.com
}

\begin{abstract}
The economic growth of Banjarnegara, Purbalingga, Banyumas, Cilacap and Kebumen regencies or known as Barlingmascakeb region is on average lower than the economic growth of Central Java Province. This study aims to analyze the influence of human capital that proxy from level of education and life expectacy, labor, and capital on economic growth in the Barlingmascakeb region. The data used is secondary data, time series starting from 2008-2015. This study uses multiple linear regression. Based on the results of the study it is known that the variable human capital, which is seen from the level of education and life expectancy, labor, capital has a positive influence on economic growth in the Barlingmascakeb region.
\end{abstract}

Keywords: Level of Education, Life Expectancy, Labor, Capital, Economic Growth.

\begin{abstract}
ABSTRAK
Pertumbuhan ekonomi Kabupaten Banjarnegara, Purbalingga, Banyumas, Cilacap, dan Kebumen (Barlingmascakeb) secara rata-rata lebih rendah dari pertumbuhan ekonomi Provinsi Jawa Tengah. Oleh karena itu penelitian ini bertujuan untuk menganalisis pengaruh human capital yang dilihat dari tingkat pendidikan dan tingkat harapan hidup, tenaga kerja, dan modal terhadap pertumbuhan ekonomi di kawasan Barlingmascakeb. Data yang digunakan adalah data sekunder, runtun waktu dimulai dari tahun 2008-2015. Penelitian ini menggunakan alat analisis regresi liner berganda. Berdasarkan hasil regresi diketahui bahwa variabel human capital, yang dilihat dari tingkat pendidikan dan tingkat harapan hidup, tenaga kerja, modal memiliki pengaruh positif terhadap pertumbuhan ekonomi di kawasan Barlingmascakeb.
\end{abstract}

Kata kunci: Tingkat Pendidikan, Tingkat Harapan Hidup, Tenaga Kerja, Modal, Pertumbuhan Ekonomi.

\section{INTRODUCTION}

Economic growth is not only important for development, its function also as a country's necessity. This is due to increasing total population every year caused by fertility. When the population increase so the necessity of goods and services increase too. Therefore, economic growth is required in order to fulfill the people's necessity. One indicator of the increase in the number of goods and services is from the rate of economic growth (Tambunan, 2013).

Indonesian economic growth in 2010 to 2015 has experiencing constant decrement. Figure 1 shows that Indonesian economic growth in 2015, which is 4.79 percent, is the lowest for last six years. The main cause of the economic growth deceleration in 2015 is due to collapse household consumption. 


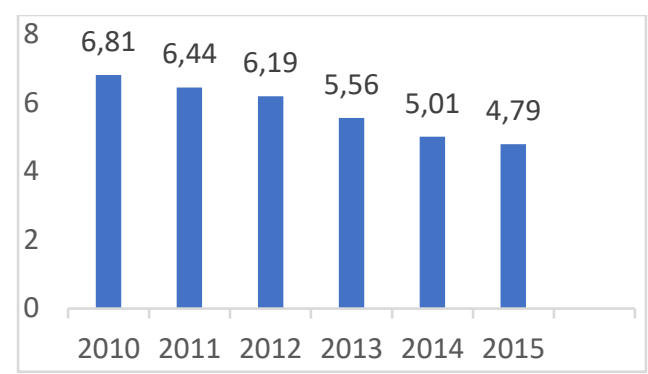

Figure 1. Indonesian Economic Growth 2010-2015 (\%)

Source: Badan Pusat Statistik, 2016

Based on Figure 1, in the 2015, household consumption only grows to 4.79 percent. Those numbers even lower compared to last two years, which reach 5.56 in 2013 and 5.01 in 2014. The decline in economic growth value in 2015 was related to the increment of food price. The high price of foods affects people to lower their spend on food.

\begin{tabular}{lcc}
\multicolumn{3}{c}{ Table 1. Economic Growth Barlingmascakeb 2011-2015 (\%) } \\
\hline Years & Central Java (\%) & Barlingmascakeb (\%) \\
\hline 2011 & 5.62 & 4.87 \\
2012 & 5.63 & 5.47 \\
2013 & 5.40 & 4.90 \\
2014 & 5.32 & 5.00 \\
2015 & 5.57 & 4.70 \\
\hline Average & 5.58 & 4.99 \\
\hline \multicolumn{3}{r}{ Source: Badan Pusat Statistik, 2016}
\end{tabular}

Different from the decreasing national economic growth in 2011 to 2015, Barlingmascakeb and Central Java economic growth tend to fluctuate. Central Java economic growth in 2011 is 5.62 percent, increased to 5.63 percent in 2012, and then decrease to 5.4 percent and 5.32 percent in 2013 and 2014, then again increase to 5.57 percent in 2015. So was the Barlingmascakeb economic growth, which once increase from 4.87 percent to 5.47 percent and later occurring decrement in 2015 to 4.7 percent.

Table 1 shows that economic growth in Central Java province averagely higher than Barlingmascakeb. Central Java economic growth averages from 2011 to 2015 is 5.58 percent, while Barlingmascakeb economic growth averages is 4.99 percent. This means that Barlingmascakeb economic growth still below the averages economic growth of regions or cities in Central Java Province.

Beside lower than Central Java economic growth, Barlingmascakeb economic growth also tend to less qualified. This condition is shown on the Table 2 below.

Table 2. Economic Growth toward Employment Growth in Barlingmascakeb Year 2011-2015

\begin{tabular}{lcccc}
\hline Years & $\begin{array}{c}\text { Employment } \\
\text { Growth } \\
(\%)\end{array}$ & $\begin{array}{c}\text { Economic } \\
\text { Growth } \\
(\%)\end{array}$ & Elasticity & Result \\
\hline 2011 & 5.70 & 5.62 & 1.36 & Elastic \\
2012 & 7.69 & 5.63 & 0.60 & Inelastic \\
2013 & 3.40 & 5.40 & 0.46 & Inelastic \\
2014 & -2.50 & 5.32 & -0.50 & Inelastic \\
2015 & -2.70 & 5.57 & -0.48 & Inelastic \\
\hline Average & \multicolumn{5}{c}{0.44} \\
\hline \multicolumn{5}{c}{ Source: Badan Pusat Statistik, 2016 }
\end{tabular}


From Table 2 can be known that from 2012 to 2015 the economic growth elasticity towards employment in Barlingmascakeb is inelastic. Economic growth elasticity average in Barlingmascakeb is 0.44 percent. This means 1 percent of economic growth in Barlingmascakeb will only increase employment to 0.44 percent. In other word, when Barlingmascakeb government wants an employment, they have to increase their economic growth higher.

Barlingmascakeb is a supervision area which covers, Banjarnegara, Purbalingga, Banyumas, Cilacap, and Kebumen regions with a development function as central services for local, province, and national. The total area of Barlingmascakeb is 659,623 hectare and with the total population of $6,233,030$ people, about 33.20 percent of total population in Central Java (Badan Pusat Statistik, 2013). Barlingmascakeb potencies are consist of agriculture with total productivity 308.1 quintal per hectare. Seen from plantation crops production in Barlingmascakeb region, Kebumen is the highest with total amount of 63.35 quintal per hectare. Every region has its own different potencies consistent with its own characteristic. Banyumas has a durian plantation and the quite large Durian producer. Purbalingga has many industries such as the wigs and eyelashes. As for Banjarnegara, it has abundant fruits and vegetables plantation. As for Cilacap, beside of its abundant fishery, it's also has the widest area of Barlingmascakeb, consist of 213,851 hectare. Cilacap is also the highest populated region with total population of 1,679,864 (Badan Pusat Statistik, 2013).

According to Solow Model (1970), this research more focused on economic growth is affects by human capital, labor and capital. This theory assumes that economic growth concern the human capital, labor and capital. Human capital is a variable within economic growth which explicitly have an equal value with other variable (Todaro, 2006). Research conducted by Teixeira and Queiros (2016) and Acemoglu, Gallego, and Robinson (2014) also explains that human capital is positively affecting economic growth. In long terms condition, human capital will significant and positively affecting outputs and technical advances, because human capital has a central role and most important factor in order to increase economic growth.

Labor positively affects economic growth due to the assumption of labor as stimulant and booster to economic growth (Lee and Hong, 2012). The research result conducted by Sayekti (2009) and Lubis (2014) is also declares that labor affects positively to economic growth. With the increment of labor that working in various sector, goods and services will gain, thus will increasing real wage rates. Beside of that, labor with high productivity will be considers as booster factor in accelerating economic growth in certain area.

Capital is main component to elevate a nation economic. Capital becomes the most important factor to achieve high economic growth. Capital has positive influences in economic growth due to its role as the main wheels in economics activity. Hence, it is important for achieving economic growth (Cuaresma, Doppelhofere, and Feldkircherf, 2014). The research result conducted by Iskandar (2012) and Bado (2013) is also declares that capital is positively affects economic growth. The larger the capital, the faster economic will grows. Capital has important role to supports the economic growth.

This research will reviewing the determinants of economic growth in Barlingmascakeb. Utilizing Solow Model, exclusively this research will analyze the influence of human capital, labor and capital on economic growth. This research is intended to uncover factors affecting the economic growth of Barlingmascakeb, by reviewing variables of human capital, labor, and capital because these variables are considered as vital keys in economic growth.

\section{RESEARCH METHOD}

\section{Object Research}

The object of this research is the area of Barlingmascakeb, consists of regencies of Banjarnegara, Purbalingga, Banyumas, Cilacap, and Kebumen Regency.

\section{Types and Sources of Data}

Type of data used in this research is secondary data. Secondary data is data obtained directly through the results of the reports of a research. Data sources used in the study are obtained from Badan 
Pusat Statistik (BPS) and Dinas Penanaman Modal dan Pelayanan Terpadu Satu Pintu (DPMPTS). The data used are those within the years 2008-2015 period.

\section{Data Collection Techniques Research}

The method used in this study is documentation. Research conducted with library materials in the form of scientific writings, and reports of scientific research related to the the topics examined. Data collection technique used is to do the recording directly in the form of time series data of the year 2008-2015.

\section{Opertional Definition}

\section{Economic Growth}

Economic growth in the research is percentage changes of Gross Domestic Regional Product (GDRP) of 5 region. Economic growth formulated as follows:

$$
\text { Economic Growth }=\left(\mathrm{GDRP}_{\mathrm{t}}-\mathrm{GDRP}_{\mathrm{t}-1}\right) / \mathrm{GRDP}_{\mathrm{t}-1} \times 100 \%
$$

\section{Level of Education}

The level of education is defined as the length of time a person is educated.

\section{Life Ecpectancy}

Life expectancy is the average year of life that a person will still live in a certain year.

Labor

The number of residents aged 15-64 years in each district in the Barlingmascakeb region.

\section{Capital}

Capital is defined as the sum of domestic investment and foreign investment in units of billion rupiah.

\section{DATA ANALYSIS TECHNIQUE}

\section{Panel Data}

To know the influence of human capital, labor, and capital towards economic growth in Barlingmascakeb, it uses multiple linear regression analysis as follows (Ghozali, 2009):

$$
Y_{i t}=\alpha+\beta_{1} X_{1 i t}+\beta_{2} X_{2 i t}+\beta_{3} X_{3 i t}+\beta_{4} X_{4} \text { it }+e
$$

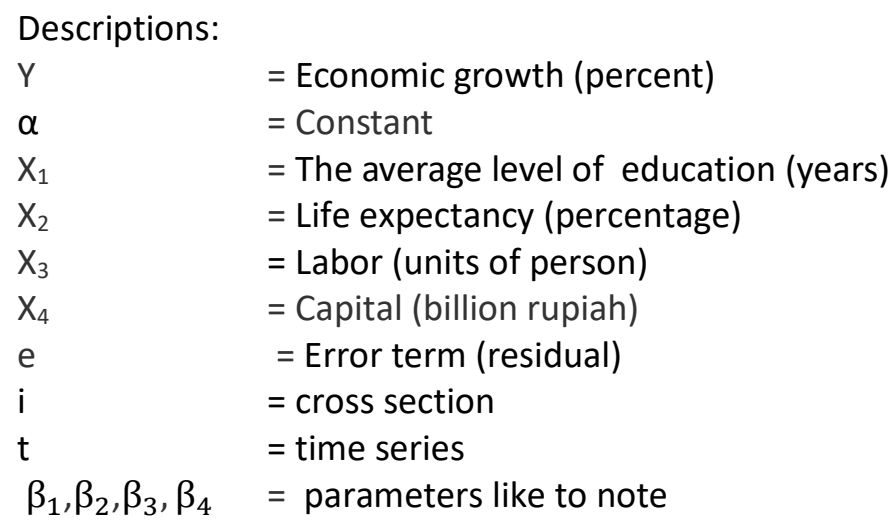




\section{ANALYSIS RESULT}

\section{Research Results}

To be able to analyze the effect of human capital, labor, and capital in economic growth on Barlingmascakeb, this study uses multiple linear regression analysis. The regression equation obtained from the results of SPSS and Eviews 9 calculation is as follows:

$$
Y=-8.987324+0.001129 X_{1}+0.182983 X_{2}+0.000002 X_{3}+0.000193 X_{4} \ldots
$$

Based on equation 2, then it can be taken a few conclusions as follows:

(1) Coefficient value of the average level of education is 0.001129 . Its coefficient indicates the average level of education that an increase in the average level of education 1 years, so economic growth also increases is 0.001129 percent.

(2) Coefficient value of life expectancy is 0.182983 . Its coefficient indicates life expectancy that an increase in life expectancy 1 percentage, so economic growth also increases is 0.182983 percent.

(3) Coefficient value of labor is 0.000002 . Its coefficient indicates labor shows that an increase in the workforce 1 units of person, so economic growth also increases is 0.000002 percent.

(4) Coefficient value of capital is amounted to 0.000193. Its coefficient indicates capital shows that in case of an increase of capital 1 billion rupiah, so economic growth also increases 0.000193 percent.

\section{Classical Assumption Test}

\section{Normality Test}

Normality test of data is done with the test using test of Jarque Berra Eviews program, and a gaussian data if the value of Asymp Sig (2-tailed) $>\alpha(0.05)$. The result of Jarque Berra Test is 9.722 with probability this is greater than 0.05 alpha level.

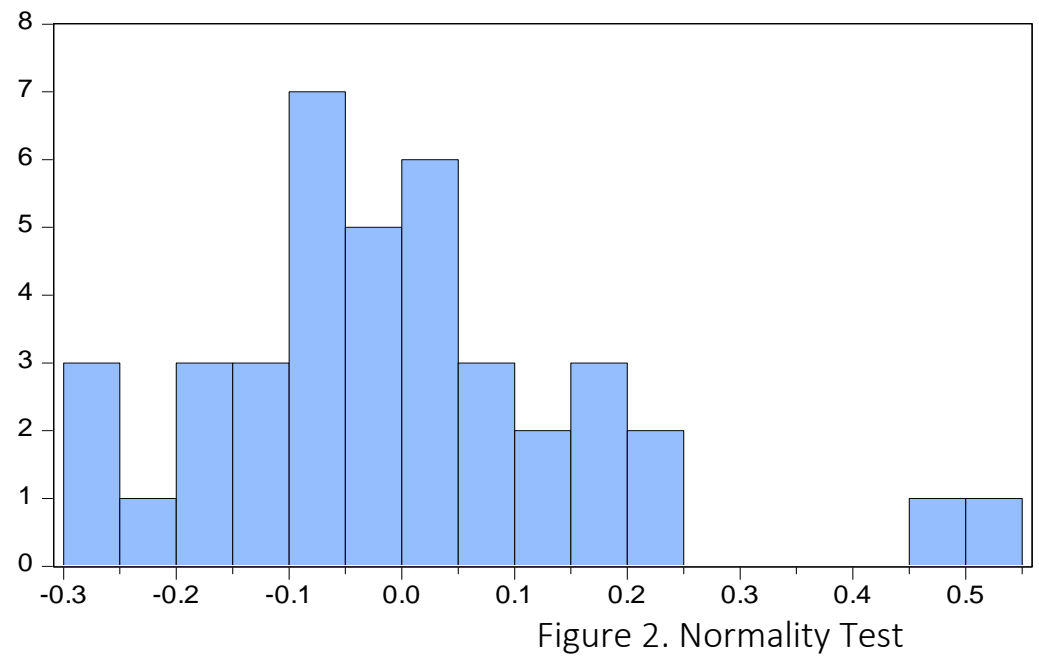

\begin{tabular}{|lr|}
\hline \multicolumn{2}{|l|}{ Series: Residuals } \\
Sample 1 40 \\
Observations & 40 \\
Mean & $-5.81 \mathrm{e}-16$ \\
Median & -0.022983 \\
Maximum & 0.501198 \\
Minimum & -0.298182 \\
Std. Dev. & 0.173483 \\
Skewness & 0.944547 \\
Kurtosis & 4.504868 \\
& \\
Jarque-Bera & 9.722170 \\
Probability & 0.07742 \\
\hline
\end{tabular}

Accordingly, the data used to analyze economic growth in Barlingmascakeb are no significant or having normal distribution. Therefore, the data in this study are to be used for further analysis.

\section{Multicollinearity Test}

Based on the value of the variance inflation factors (VIF), the values of all variables VIF are not more than 10. Then, all independent variable in this research are free from the symptom of multicollinearity. 


\section{Heteroscedasticity Test}

Based on the results of a test of glejser, the significance of the average level of education is value, 0.799 , significance of life expectancy is 0.725 , significance of labor is 0.842 . So, the significance of the average level of education, life expectancy, labor, and capital is above 0,05 percent. Therefore, the model in this study does not contain problem heteroscedasticity.

\section{Autocorrelation Test}

The result of the calculation indicate that the value of the Durbin Watson is 1.869 . Based on the Durbin Watson with table $\alpha=0,05$ percent, $\mathrm{k}=4$ and $\mathrm{n}=40$, a value of $d_{l}=1.285$ and $d_{u}=1.721$ or value $4-d_{l}=2,715$ and $4 d_{u}=2.299$. Then Dw value lies between $d_{u}=1.721$ and $4-d_{u}=2.299$. It can be inferred that the model in this research are free from the problem of autocorrelation.

\section{Statistical Testing}

\section{$t$ Test}

If $t_{\text {statistic }} \leq t_{\text {table }}$ then $H_{0}$ is accepted and $H_{a}$ is rejected, when the test is done partially. To know the influence partially the average level of education, labor, and capital towards economic growth in Barlingmascakeb, a significant value is used.

From the analysis results by using the significant level $(\alpha)=0.05$, it is known the significant of variable life expectancy is 0.046 , labor is 0.026 , and capital is 0.001 all are smaller than the value of alpha level 0.05 .

The significant value of the average level of education is 0.964 or greater than the value alpha level 0.05. Therefore, variables of life expectancy, labor, and capital are accepted because these variable have significant influence on economic growth in Barlingmascakeb. Meanwhile, the average level of education is rejected because it has no significant effect on economic growth in Barlingmascakeb.

\section{Determination Coefficient $\left(R^{2}\right)$}

From multiple regression analysis, the result of the value of the adjusted $R$ Square is 0.825 . This shows that economic growth in Barlingmascakeb can be explained by the variables of the average level of education, life expectancy, labor, and capital by $82.5 \%$.

\section{F Test}

The result of calculation with confidence 95 percent or $\alpha=0.05$ obtains significant value of 0.000 which is smaller than of $(\alpha)=0.05$. It indicates the average level of education, life expectancy, labor and capital simultaneously affect the economic growth in Barlingmascakeb.

\section{DISCUSSION}

\section{The Influence of The Average Level of Education to Economic Growth in Barlingmascakeb}

The average level of education has no significant influence to economic growth. Coefficient value of the average level of education is (0.001129). Its coefficient indicates the average level of education that an increase in the average level of education 1 years, so economic growth also increases is 0.001129 percent. This condition is in accordance with the tested hypothesis. This is supported by Salsabila (2013) who said that the average level of education does not have a positive impact to economic growth. In contrast, the result of the research by Aminnudin (2013) and Saepudin (2011) mentioned that the average level of education has a positive influence to economic growth. Because the average level of education in Barlingmascakeb is as high as 8.61 percent in the year 2015, then it should have an effect on economic growth.

\section{The Influence of Life Expectancy to Economic Growth in Barlingmascakeb}

Life expectancy has positive and significant influence to economic growth. Coefficient value of life expectancy is (0.182983). Its coefficient indicates life expectancy that an increase in life expectancy 1 percentage, so economic growth also increases is 0.182983 percent. This condition is in accordance 
with the tested hypothesis. This is supported by the research by Aminnudin (2013) and Saepudin (2011) which stated that life expectancy has a positive and significant influence toward economic growth. The result of this research is not in accordance with the results of the research by Pambudi (2013), that negative influence of life expectancy on economic growth caused by levels of health.

The quality of the human capital of an area can be indicated by looking at the condition of the quality of health care. Health is described through the life expectancy. Statistically, life expectancy in Barlingmascakeb affects the economic growth with significant level. The higher life expectancy, then the more productive human capital. In turn, it would increase economic growth.

\section{The Influence of Labor to Economic Growth in Barlingmascakeb}

Labor has positive and significant influence to economic growth. Coefficient value of labor is (0.000002). Its coefficient indicates that an increase in the workforce 1 units of person, so economic growth also increases is 0.000002 percent. This condition is accordance with the tested hypothesis. This is supported by Sayekti's (2009) and Lubis's (2014) research which stated that labor variable has positive effect to economic growth. This research are not in accordance with the results of the research by Juardi's (2014) stating that labor has no significant effect on economic growth. An increasing number of labor working in various sectors, it will increase the amount of goods and services produced and would raise the level of real wages. In addition, this workforce with high productivity is regarded as a driving factor in accelerating the process of economic sector growth in the region.

\section{The Influence of Capital to Economic Growth in Barlingmascakeb}

Capital has positive and significant influence to economic growth. Coefficient value of capital is (0.000193). Its coefficient indicates that an increase of cspital 1 billion rupiah, so economic growth also increases is 0.000193 percent. This condition is accordance with the tested hypothesis. This is supported by the research by Iskandar (2012) and Bado (2013) which also stated that capital has the positive effect toward economic growth. This research is not in accordance with the results of the research conducted by Bati (2009), Anwar (2011), and Wardihan (2012) which found that capital does not have significant influence to economic growth. The capital has a positive influence in economic growth as a driving force in economic activities. If the capital increases, economic growth also increases.

\section{CONCLUSION}

(1) Based on F Test, as an indicator of human capital, the average level of education, life expectancy, labor, and capital simultaneously has significant effect to economic growth in Barlingmascakeb.

(2) Partially, life expectancy, labor, and capital has positif effect to economic growth in Barlingmascakeb.

(3) Based on of the elasticity value that have most variable influence to economic growth in Barlingmascakeb is life expectancy.

\section{IMPLICATION}

Based on the results and discussion, the implications of this study are as follows:

(1) As an indicator of human capital, the average level of education has positive influence to economic growth. When the government of a region wants to increase its economic growth, then the government should create employment that can absorb labor. So, the graduates or those who had completed education not more into other areas, and willing to work in Barlingmascakeb. The local governments provide socialization of education by establishing education compulsory program until the secondary school, to improve the quality of human resources in the aspect of education. 
(2) Life expectancy has positive influence to economic growth in Barlingmascakeb. The local governments should perform health staff empowerment potential in the field of health, and other health resources utilizing in Barlingmascakeb to be involved in the increase in life expectancy. The higher life expectancy then the more productive the society members.

(3) Labor has positive influence to economic growth in Barlingmascakeb. When local governments in Barlingmascakeb need to improve the quality, quantity, and training for the workforce to be more skilled, the local governments and the public should have cooperation in improving workforce. So, the economic growth will automatically increases.

(4) Capital has positive influence to economic growth in Barlingmascakeb. Then, the government should further improve the service to investors by easing license procedures and facilitating, and creating a conducive in order for the investors to invest in Barlingmascakeb.

\section{LIMITATION}

Limitations in this study are on the time period and the variables used. This study only takes eight years from 2008 to 2015 and uses only four variables, namely human capital divided into two is the average level of education and life expectancy. Labor, and capital due to the limited available data.

\section{REFERENCES}

Acemoglu, Daron, Gallego, Francisco A. \& Robinson, James A. (2014). Institusions, Human Capital, and development. Annual Review of Economics, 6(1), 875-912.

Amin. (2013). Pengaruh Belanja Modal, Dana Perimbangan, dan Kemandirian Fiskal Terhadap Pertumbuhan Ekonomi Daerah (Studi Empiris Pada Pemerintahan Kabupaten atau Kota di Pulau Jawa periode 2006-2010 Skripsi. FE UI: Juli

Anwar. (2011). Peran Modal Manusia Terhadap Pertumbuhan Ekonomi Regional di Jawa. Jurnal Economia, 13(1).

Badan Pusat Statistik Indonesia. (2016). Pertumbuhan Ekonomi di Indonesia Tahun 2010-2015. Accessed on 25 March 2017.

Badan Pusat Statistik Indonesia. (2016). Pertumbuhan Ekonomi di Jawa Tengah dan Barlingmascakeb tahun 2011-2015. Accessed on 14 November 2017.

Badan Pusat Statistik Indonesia. (2016). Elastisitas Pertumbuhan Ekonomi Terhadap Penyerapan Tenaga Kerja Menurut Kabupaten Barlingmascakeb di Jawa Tengah tahun 2011-2015. Accessed on 14 November 2017.

Badan Pusat Statistik Indonesia. (2016). Pertumbuhan Ekonomi di Barlingmascakeb Tahun 20082015. Accessed on 25 March 2017.

Badan Pusat Statistik Indonesia. (2016). Rata-rata lama sekolah di Barlingmascakeb Tahun 20082015. Accessed on 17 September 2017.

Badan Pusat Statistik Indonesia. (2016). Angka Harapan Hidup di Barlingmascakeb Tahun 2008-2015. Accessed on 17 September 2017.

Badan Pusat Statistik Indonesia. (2016). Tenaga Kerja di Barlingmascakeb Tahun 2008-2015. Accessed on 17 September 2017.

Badan Pusat Statistik Indonesia. (2016). Modal di Barlingmascakeb Tahun 2008-2015. Accessed on 18 September 2017.

Bado. (2013). Analisis Belanja Modal, Investasi, dan Tenaga kerja Terhadap Pertumbuhan Ekonomi Sulawesi Selatan. Jurnal Ilmiah Econosains, 14(2), Agustus 2016

Cuaresma, Jesús Crespo, Doppelhofere, Gernot, \& Feldkircherf, Martin. (2014). The Determinants of Economic Growth in European Regions. Region Studies, 48(1), 44-67. 
Ghozali, Imam, (2009). Ekonometrika. Teori, Konsep dan Aplikasi dengan SPSS 17. Semarang: Universitas Diponegoro.

Lee, Jong-Wha \& Hong, Kiseok. (2012). Economic growth in Asia: Determinants and prospects. Japan and The World Economy, 24(2),101-113.

Lubis. (2014). Pengaruh Jumlah Tenaga Kerja, Tingkat Pendidikan Pekerja dan Pengeluaran Pendidikan Terhadap Pertumbuhan Ekonomi. Jurnal Economia, 10(2).

Teixeira, Aurora A C \& Queiros, Anabela S S. (2016). Economic growth, human capital and structural change: A dynamic panel data analysis. Research Policy, 45(8),1636-1648.

Todaro, M.P. (2006). Pembangunan Ekonomi. Edisi 9. United Kingdom: Pearson Education Limitied. 